7 (2) 2020 EDITORS: ANNA BENDRAT, ELŻBIETA PAWLAK-HEJNO

VARIA

IWONA ŚWIĄTCZAK-WASILEWSKA

INSTITUTE OF LINGUISTICS AND LITERARY STUDIES,

UNIVERSITY OF NATURAL SCIENCES AND HUMANITIES IN SIEDLCE, POLAND

https://orcid.org/0000-0003-4397-3403

iwona.swiatczak-wasilewska@uph.edu.pl

\title{
The Failure of Legislative Leadership: A Retrospective Study of Crafting the State of the Unions in the George H. W. Bush White House Porażka przywództwa: analiza powstawania orędzi o stanie państwa w czasie prezydentury George'a H. W. Busha
}

\begin{abstract}
The analysis of the archival documents illustrates that speechwriting in the George H. W. Bush White House was decentralized and responsibility for crafting Bush Senior's State of the Unions (SOTUs) was diffused among a team of different writers each year. George H. W. Bush would not use his SOTUs as an opportunity to assert his legislative leadership. The preferred structure of Bush Senior's SOTU was a thematic, not a programmatic speech. The study concludes that a speechwriting process that fails to balance the ceremonial and deliberative aspects of the SOTU undermines the president's opportunity to assert his legislative leadership.

Analiza dokumentów powstałych w trakcie prezydentury George’a H. W. Busha ukazuje, że odpowiedzialność za tworzenie prezydenckich orędzi o stanie państwa każdego roku spoczywała na innym zespole autorów. Bush Senior nie wykorzystywał swoich orędzi jako okazji do zaakcentowania swojego przywództwa ustawodawczego. Prezydent i jego doradcy preferowali orędzia tematyczne, a nie programowe. O ile takie podejście może mieć uzasadnienie w nadzwyczajnych momentach historii, gdy ważne jest zjednoczenie narodu wokół jakiegoś działania, idei czy wartości, nie sprawdza się ono jako dominująca strategia komunikacyjna w orędziach o stanie państwa, którego istotą jest przywództwo ustawodawcze. Mowa, która nie spełnia kryteriów orędzia jako gatunku retorycznego, uniemożliwia prezydentowi zaistnienie w roli inicjatora procesu ustawodawczego.
\end{abstract}

\section{Key words}

George H. W. Bush, state of the union, speechwriting, wordsmiths, leadership George H. W. Bush, orędzie o stanie państwa, pisanie przemówień, przywództwo

\section{License}

This work is licensed under a Creative Commons Attribution 4.0 international (CC BY 4.0). The content of the license is available at http://creativecommons.org/licenses/by/4.0/ 


\section{The Failure of Legislative Leadership: A Retrospective Study of Crafting the State of the Unions in the George H. W. Bush White House}

\section{Introduction ${ }^{1}$}

This paper seeks to address the following questions: 1) who generated input for the State of the Union Addresses (SOTUs) under president George H. W. Bush; 2) what was the role of key presidential speechwriters and how well were these individuals linked to the White House policy processes. The organizational pattern that emerged from the analysis of archival documents from the George H. W. Bush White House illustrates that speechwriting was then decentralized and responsibility was diffused among a team of different writers each year. Bush Senior's SOTUs were thematic, not programmatic speeches. The president would not seek to provide legislative leadership through his SOTUs. These findings illustrate that a speechwriting process that fails to meet the expectations of a SOTU as a rhetorical genre undermines the president's opportunity to assert his leadership as the chief legislator.

\section{Speechwriters in the White House}

Speechwriting dates to the presidential years of George Washington. His famous Farewell Address, for instance, was ghosted by Alexander Hamilton. Only a few presidents, including Thomas Jefferson, James Madison, Abraham Lincoln, Theodore Roosevelt, and Woodrow Wilson, wrote their speeches. The Wilsonian doctrine of presidential leadership encouraged frequent public appeals and increased the number of speeches delivered by the president (Tulis 1987).

It was not until the 1920s, however, that the White House hired a speechwriter. Judson Welliver was the first White House staff person whose chief responsibility

1. This article is based on parts of my unpublished doctoral dissertation (Świątczak-Wasilewska 2014) relating to George H. W. Bush. This study would not be possible without the Peter and Edith O’Donnell Grant awarded by the George Bush Presidential Library Foundation (Scowcroft Institute of International Affairs). 
was to craft oratory for president Warren Harding, reportedly because the president's English reminded "of dogs barking idiotically through endless nights," (Schlesinger 2008, 3). Already in the 1880s, Chester Arthur employed a friend named Daniel Rollins to help draft presidential messages. As ghostwriting "would have been an unthinkable sharing of responsibilities at the end of the nineteenth century, Rollins went to great pains to keep his help to the ailing Arthur a total secret," (Denton and Woodward 1998, 205).

Speechwriters remained a rarity until the Administration of Calvin Coolidge in 1923 and the advent of radio. Coolidge vastly increased the number of presidential speeches with the assistance of Judson Welliver and others. By establishing this precedent, the perception of the president's office changed. The president would start to be perceived as a leader "whose fate was determined by the quality of his staff as well as his own efforts," (Denton and Woodward 1998, 206). It was not until the Nixon presidency that speechwriting became institutionalized with the establishment of the White House Office of Speechwriting.

Karen M. Hult and Charles E. Walcott (1998, 467) argue, however, that the emergence of the disjunction of policy deliberations and speechwriting can be traced to the Johnson presidency. Until then, "presidential policy concerns drove presidential speechwriting.” People participating in the policy processes and the structure of the speechwriting organization were important. Presidents would rely on the help of their top advisors in connecting presidential speechwriting with policy deliberations. The president would be an active participant "in writing sessions, providing guidance from the top of the White House hierarchy;” and speechwriting would provide an occasion for policy deliberations.

Since LBJ, policymakers would cease to dominate the speechwriting process. Hult and Walcott $(1998,466)$ argue that "writing is now typically delegated to professional speechwriters who are often weakly connected to the President and the policy deliberation process," and "often too poorly informed about administration objectives and policy proposals to write accurately and persuasively about them.”

Also, because Nixon restructured the speechwriting organization by creating a separate White House office for speechwriters, the integration of the policymaking with speechwriting would be frustrated. Thus, the shift initiated by LBJ and furthered by Richard Nixon resulted in "a growing disjunction between the content of presidential statements and the clear and accurate expression of administration goals and policy initiatives,” (Hult and Walcott 1998, 467). The increased number of Special Assistants and aides concerned with public relations and speechwriting is "one of the more disquieting aspects of the recent enlargements of the presidential establishment,” (Denton and Woodward 1998, 205). 
Although ghostwriters and speechwriters are used interchangeably, ghostwriters' activities are concealed, while the activities of speechwriters are known (Campbell and Jamieson 1990, 225). Wordsmiths or speechwriting specialists (Tulis 1987, 2017), are a relatively new development. Their talent "is to translate the political policies of others into persuasive prose. They need not have, and increasingly do not have substantive expertise, but they do sometimes specialize in various aspects of persuasion,” (Tulis 2017, 184). As Kenneth Colliers $(2018,12)$ points out, "[s]peeches are the product of the complex institutional arrangements of the speechwriting process. The presidency may speak with one voice, but its message often reflects the effort of many minds."

During the George H. W. Bush years, the White House Communications Office (WHCO) functions included speechwriting, media relations, and intergovernmental communications. David Demarest served as the director of the WHCO during most of Bush Senior's term. The staff was headed by Chriss Winston, who mainly assigned speeches and edited drafts and was later substituted by Tony Snow. Other writers included Mark Davis, Curt Smith, Dan McGroarty, Mary Kate Grant, Jennifer Grossman, Mark Lange and Robert Simon. The drafting of Bush's SOTUs was undertaken by a team of various speechwriters each year.

Mark J. Rozell's (1998) interviews with President George H. W. Bush's White House staff reveal that writers had limited access to the president. Tony Snow (Rozell 1998, 129) described Bush Senior's relationship with the writers as “distant.” Andrew Furgeson (Rozell 1998, 129) pointed out that the "White House attached very little importance to speechwriting" and that the president did not consider it "very important."

This following study provides additional insight into speechwriting operations in the White House based on the analysis of archival materials pertaining to crafting a uniquely presidential genre - the State of the Union address (SOTU) during the George H. W. Bush presidency.

\section{The SOTU as a tool of legislative leadership and a rhetorical genre}

The SOTU, as Griffin $(2003,69)$ points out, has become one of the most "significant and complex undertakings" of the Rhetorical Presidency (Ceaser et al. 1981; Tulis 1987) and "a uniquely presidential genre of discourse," (Campbell and Jamieson 1990, 52). The speech, Hoffman and Howard (2006, 2) argue, has been "instrumental in the development of the president's role as chief legislator." As the authors point out (93-95), the SOTU increased the president's visibility, activism, openness of Congress to presidential leadership, and the social and economic need for national leadership to address national problems in the $20^{\text {th }}$ century. 
“The concept of leadership,” as Leroy G. Dorsey (2002, 5) notes, “is grounded in the nature and practice of rhetoric.” Richard Neustadt's classic work in Presidential Power, first published in 1960, advanced a view that presidential formal "powers," including that of chief legislator, "are no guarantee of power." Presidential power is "the power to persuade.” A more recent literature on presidential leadership discussed by David Zarefsky $(2002,22)$ suggests the following recurring themes,

First, presidential leadership involves rising above some baseline notion of the minimal constitutional requirements of the office. Second, the result is achieved by bringing about change-not necessarily reversal, but change. Third, the change is transformative. It outlasts the immediate circumstances and reconstructs the nature and expectations of the office over the long term. Finally, this effect is often achieved by discovering and using the available means of persuasion in a given case.

The SOTU is "a marvelous tool of political communication for chief legislators” (Hoffman and Howard 2006, 179-180) because it provides the presidents with a unique opportunity to affect transformative change through rhetoric while fulfilling two constitutional provisions, both of which rest in Article II, Section 3 "to give to the Congress information on the State of the Union, and recommend to their Consideration such Measures as he shall judge necessary and expedient.”

Throughout the George H. W. Bush presidency (Jan. 20, 1989 to Jan. 20, 1993), the president delivered three SOTUs on January 31, 1990; January 29, 1991; January 28, 1992. Bush Senior produced no SOTU in the first and the last year of his presidency. The White House Fact Sheet referred to Bush's 1990 SOTU as his "first." However, three weeks into his presidency, George H. W. Bush delivered the so-called SOTU-like "Message of President George Bush to a Joint Session of Congress, February 9, 1989,” or “Address of the Joint Session of Congress, Thursday, February 9, 1989,” in a customary SOTU timeframe.

Kalb, Peters, and Wooley $(2007,3)$ point out that beginning with the presidency of George H. W. Bush, the addresses delivered in the weeks following the inauguration are not considered State of the Unions. The difference between the SOTU and the SOTU-like speech "relates to the fact that these newly inaugurated presidents chose to place the focus of their speech on meeting election expectations rather than reporting on the past year of government."

The SOTUs, Campbell and Jamieson $(1990,68)$ point out, are "a complex rhetorical type," performing both ceremonial and deliberative functions. Meditation on the values from which assessments are made calls for ceremonial rhetoric. Legislative leadership, asserted through the president's program and policy recommendations, calls for deliberative rhetoric. The importance of both these elements is beyond dispute. Ceremonial rhetoric, Campbell and Jamieson $(1990,29)$ claim, 
may be "a precursor to deliberative decision.” Without ceremonial elements, policy recommendations have no clear basis. Deliberation, that is, "the argumentative form associated with justifying new policy” is what distinguishes a ceremonial address from policy address.

Campbell and Jamieson $(1990,73)$ argue that given

the need to celebrate the values underlying assessments and recommendations, ceremonial rhetoric is appropriate, but given the constitutional mandate and a need to establish presidential legislative leadership, deliberative rhetoric is needed to justify policy recommendations and establish legislative priorities.

Thus, the appropriate balance of the ceremonial (inspirational, thematic, value-oriented) and deliberative (specific, programmatic, policy-oriented) rhetoric is an essential requirement of the SOTU if the president wants to make the most of the opportunity to act as the chief legislator.

\section{Crafting SOTUs in the George H. W. Bush White House}

The preferred structure of the Bush Senior's SOTUs was a thematic (or ceremonial), not a programmatic (or deliberative) speech, in which American values played an important role. The research in the history of the SOTU carried out by the White House staff had likely influenced the president's preference for thematic SOTUs. The research concluded that

strong Presidents in America's past who have seized the initiative in setting a legislative course for the country have without exception delivered more thematic State of the Union addresses. These presidents, including Jackson, Lincoln, Cleveland, Wilson, and both Roosevelts, had voiced an overall view of "the state of the union;" where the country is and where it should be going, rather than offering itemized list of presidential programs. Abraham Lincoln, Woodrow Wilson and Franklin Roosevelt are the three all-time champions of the effective State of the Union address. These men all served in times of national crisis, leaving no doubt that they were leading the nation. All three chose not only to deliver more thematic annual messages, but shorter ones also, (Demarest to the President).

Although a remarkable number of historical events and international crises all over the world ${ }^{2}$ confronted the presidency of George H. W. Bush, the way a president responds to external situations is only one of the measures of a successful president. Another critical component of the president's role as chief executive is his prominent role in the legislative process. George H. W. Bush, however, lacked a legislative agenda (Rose 1991). The president was never able to succeed in the domestic arena, and several factors account for Bush's lack of success in domestic

2. These events and crises included the Tiananmen Square massacre, the invasion of Panama, the Persian Gulf war, the collapse of the Berlin War, the end of the Cold War and the unification of Germany. 
policy, including the divided government, an uncooperative Congress, and a large deficit.

The advantage of thematic and value-oriented SOTUs was that they allowed the President to reach and move the people. This was an interesting move by the president who, as Catherine Langford $(2006,28)$ argues, "understood his role in the national drama in negative, rather than positive terms" as " "the head of government,' preventer of bad laws, and protector of the status quo.” Deputy Assistant to the President for Domestic Policy Charles Kolb (Kolb to Snow) wanted the president's supporters to think to themselves, “Damn right!” after the president finished his SOTU. Moreover, Kolb noted, "[l]itanies of programs and spending increases don't provoke a “Damn right!” response;” “[p]rogram and budget talk is inside-the beltway-talk.”

\section{Dan McGroarty and Peggy Dooley}

Dan McGroarty and Peggy Dooley were responsible for drafting Bush Senior's 1990 SOTU. Peggy Dooley was a researcher, and Dan McGroarty served as Special Assistant to President George H. W. Bush and Deputy Director of White House Speechwriting. The essential tasks of the speechwriting team included research and drafting.

Although there is very little archival evidence that speechwriters enjoyed access to president Bush Senior, the minutes from the meeting with speechwriters on January 16, 1990, illustrate that a series of meetings to discuss the first draft were held and attended by the president and Dan McGroarty, among others, with a purpose to receive a sense of direction from the president on the first draft of the SOTU. As John H. Sununu remembered in an interview with Sid Milkis,

You sit down with three or four people like this having honed the obviously inappropriate from the departments and you go and sit down with the President and you say, "Mr. President, these are the things people are looking for, what do you want in the speech?” [...] So he talks about what he wants. Then he goes over these and he indicates some preferences, and sometimes he may even craft an outline, although I think George Bush probably did less of that than other Presidents. Then you take this and you assign a head speechwriter to do the first draft. [...] This is the document, then, that is reflecting the priorities as established by the President, what he wants to emphasize and the best recommendations of his best and brightest advisors...You go over it with him and then he tells you what he really likes and what he doesn't like in it. And sometimes you have the speechwriter there for that draft, sometimes you don't. But let's assume you do. So the speechwriter comes in. The speechwriter is writing frantically, trying to keep the notes of the details, and he hears the President say a nice phrase about this and a nice phrase about that and if the speechwriter is any good he will capture some of the President's spontaneous phrases on issues, because he wants to capture him into the speech. 
The McGroarty/Dooley drafts developed between January 11 and January 29, 1990. Most of the substantive content of the address was developed in the first draft.

James Cicconi, deputy Chief of Staff to President George H. W. Bush, and not the speechwriters, submitted the first draft of the SOTU to the president along with a memo on January 12, 1990, and requested his "general impressions of the draft, its directions and tone.” The draft was not circulated at that point and did not reflect any staff comments.

Assistant to the President for Economic and Domestic Policy, Roger B. Porter, solicited, received and coordinated the material for the SOTU throughout the Bush Senior presidency. Porter (Porter to Truly, Dec. 14, 1989) was interested in what the president should articulate in that address "with respect to assessing the past year and with respect to charting the coming year, and indeed, his vision for the 1990s," and in specific policy initiatives. Porter's job, as his memo to Secretary of Transportation, Samuel K. Skinner (Dec. 11, 1989) illustrates, also involved meetings with crucial Administration officials, including Skinner, or Education Secretary Lauro F. Cavazos to discuss their ideas for the address.

McGroarty/Dooley Draft \#2 of January 18, 1990, 5:45 p. m. shows that the State Department and the National Security Council, Secretaries Baker and Cheney, would be asked to develop the foreign affairs section of the SOTU. Their memoranda were to be sent directly to Scowcroft, "rather than be folded into the domestic review that Roger Porter” was conducting. As of January 26, 1990, the draft of the foreign policy section (Hughes to Roy) was restricted to "the seventh floor principals" - the department's top staffers. The suggestions offered by the State Department (State Department Suggested Changes to State of the Union Address, January 26, 1990) were minor and submitted to "strengthen" the argument and "flesh out" the structure.

A tentative SOTU draft schedule suggests that the drafts were distributed for comments mainly among the core group of the White House staffers, or as Hill and Williams noted $(1994,12)$, “a coterie of senior advisers.” Throughout the Bush presidency, the group included Chief of Staff John H. Sununu, Director of the Office of Management and Budget (OMB) Richard Darman, General Scowcroft, National Security advisor, Roger Porter, Jim Cicconi, Ed Rogers and Andy Card, Assistant to the President and Deputy Chief of Staff.

As subsequent drafts ensued, the formal close hold staffing expanded to include the Vice President (Cicconi to Winston, Jan. 30, 1990), the core group of the White House staffers, and SOTU coordinating group: the Secretary of the Cabinet David Q. Bates, White House Press Secretary Marlin Fitzwater, White House Counsel C. Boyden Gray, Frank McClure and Chairman of Council of Economic Advisers Mike Boskin (McGroarty/Dooley draft, January 29, 1990; Memo from Cicconi to 
Chriss Winston, Jan. 30, 1990; The Advanced Text of Remarks by the President on the State of the Union, Jan. 31, 1990) and the president (White House Staffing Memorandum).

The long process of reconciling the interests of the White House staff and the Cabinet, followed by extensive editing and clearance would take place. As Sununu remembered,

Darman is in there doing his bit, Cicconi is in there doing his bit. Dave Demarest now has a copy, the communications director, Marlin Fitzwater has a copy. Now it's a decent enough copy to go to maybe ten of the key staffers and they share it with anybody on their staff that is appropriate for them to do so. And it comes back. All the time, I'm keeping a checklist, if you will, Agriculture's got two goodies in there, Labor has one goody. I want to make sure that no Cabinet officer feels left out by the President. Now I have to balance for the President happiness amongst the Cabinet. [...] Then it's almost finished and you have to have it vetted by the people whose stuff you put in there. Every State of the Union address gets so edited it becomes almost sterile. It's everything for everybody in there.

The Outline of State of the Union, January 29, 1990, indicates that the address was going to be a message on the state of the Union, not the State of the government. The opening statement of George H. W. Bush's 1990 SOTU (The American Presidency Project) speech illustrates that commitment,

Tonight I come not to speak about the state of the Government, not to detail every new initiative we plan for the coming year nor to describe every line in the budget. I'm here to speak to you and to the American people about the state of the Union, about our world - the changes we've seen, the challenges we face-and what that means for America.

The SOTU exploited the theme of America as an idea in the context of post-Cold War realities and the challenges of the revolution of 1989. As McGroarty/ Dooley 9:30 pm draft (January 29, 1990) illustrates, the purpose of American foreign policy was the spread freedom in the world,

America, not just the nation but an idea, alive in the minds of people everywhere. As this new world takes shape, America stands at the center of a widening circle of freedom-today, tomorrow, and into the next century. Our nation is the enduring dream of every immigrant who ever set foot on these shores, and the millions still struggling to be free. This nation, this idea called America, was and always will be a new world - our new world.

The idea of America and its cornerstones of competitiveness, leadership, democracy, and opportunity was then exploited with relation to the domestic affairs, and how the democratic system could be improved even further at home to provide more jobs, child care alternatives, clean environment, opportunities for disabled Americans, housing, and others. The draft emphasized that "dreams alone won't get us there. We need to extend our horizon, commit to the long view. And 
our mission for the future starts today.” It was personal responsibility and values, rather than government responsibility, that would help Americans achieve their goals,

\begin{abstract}
The state of the Government does indeed depend on many of us in this very chamber. But the state of the Union depends on all Americans. We must maintain the democratic decency that makes a nation out of millions of individuals [...]. The state of the Union depends on whether we help our neighbor-claim the problems of our community as our own. We've got to step forward when there's trouble, lend a hand, be what I call a point of light to a stranger in need. We've got to take the time after a busy day to sit down and read with our kids, help them with their homework, pass along the values we learned as children. That's how we sustain the state of the Union. Every effort is important. It all adds up. It's doing the things that give democracy meaning. It all adds up to who we are and who we will be. Let me say that so long as we remember the American idea, so long as we live up to the American ideal, the state of the Union will remain sound and strong.
\end{abstract}

Following the address, one television commentator noted (White House News Summary) that from the president's point of view, it was an "unquestionably effective" speech. The distinction between the state of the Union and the state of the government was "useful" for the president at a time when he did not propose much in the way of new programs and spending.

The post-SOTU notes from American citizens following Bush Senior's 1990 televised SOTUs provide evidence, however, that the thematic addresses yielded the response Kolb intended. There was a sense that the president's SOTU was an act of national unification. As one viewer noted (Al Flora to President Bush), “[t] he applauses and standing ovations by members of congress, Republicans and Democrats, is proof that the red, white and blue is America and you, Mr. President. [...] Mr. President, "Keep Punchin" for the principles and ideals which America stands for."

A 10:30 Draft of the President's State of the Union Message, January 31, 1990, shows that changes were made at the last moment and were incorporated into the draft by stapling or gluing small pieces of paper with new text on the original draft. The handwritten edits were incorporated into the Latest, 2:25 p.m. draft of the President's SOTU. James Cicconi and Brent Scowcroft contributed final inserts on forging new initiatives and relations with Far East, Eastern Europe, and the Soviets and serving the cause of peace by defending American interests and ideals (Undated possible inserts for State of the Union '90).

\title{
Jennifer Grossman and Mark Lange
}

The 1991 SOTU was drafted by a Harvard graduate, Jennifer Grossman, and Mark Lange, with an MBA from Stanford. As Lange/Grossman State of the Union Address Draft B-1, January 28, 1991, illustrates, the process of staffing the speech 
was similar under the McGroarty and Dooley team. As the drafts ensued, new ideas were considered (Porter to Kristol, Jan. 16, 1991). Roger Porter's job was to make sure that new ideas get "into the hopper" (Albrecht to Porter, Jan. 15, 1991). As soon as the draft (Draft B-2, January 28, 1991) started to resemble the final version, it was distributed to Scowcroft, Darman, and Grey.

Both Roger B. Porter (Kuttner to Porter) and White House Chief of Staff, Chino Chapa (Williams to Chapa) requested submissions of ideas for the budget "and the broader domestic policy agenda." As in the previous year, the idea to produce a thematic SOTU was suggested by Charles Kolb. Kolb pointed out that the 1991 SOTU would be the last opportunity for the Administration "to lay out a thematic domestic policy agenda before the 1992 election cycle begins," (Kolb to Porter, Dec. 4, 1990). He expected that two themes were likely to dominate the foreign policy aspects of the speech: the collapse of the Soviet empire and the democratization of Eastern and Central Europe, and Iraq's invasion of Kuwait. These themes were rooted in the concept of individual freedom - the pursuit and gain of which led to the unification of Germany and establishments of "Western-oriented, democratic and capitalistic governments," or, as the case of the Kuwaiti people illustrated, the temporary loss of individual freedom.

In a lengthy memorandum to John Sununu (Dec. 30, 1990), Porter presented SOTU themes which resulted from Porter's discussions with major executive departments and agencies. These discussions "yielded both much consensus and the expected interest.” The consensus concerned the value of the thematic, rather than a programmatic, approach because the programmatic approach "easily cascades into a laundry list of particular programs. It may please some specific constituencies[...], but it rarely inspires the listener or conveys a sense of direction.” This memorandum served as a starting point for drafting the outline of the SOTU on December 31, 1990.

In order to unite Americans and to retain America's global leadership position, President George H. W. Bush was advised to discuss “the good old values," (Akers et al. to the President) and to emphasize "individual freedom, decision-making, and choice," (Kolb to Porter). As the American democratic government had inspired the revolutions in Poland, Czechoslovakia, East Germany, and the Baltics, Kolb noted (Kolb to Porter, Dec. 4, 1990), "this triumph affords us the opportunity to reinforce the values and principles upon which our Republic was also founded." These values and principles suggested by Kolb included: empowerment as a way of reinvigorating an individual's, not bureaucracies'; control over the governance of one's life; the importance of growth incentives; warning against excessive reregulation; principle of individual responsibility of parents, teachers, principals and students in learning and education; "a new anti-quote, pro-jobs civil rights bill that 
will have as its centerpiece "the principle of personal economic opportunity and liberty [...]," and "the principle of freedom from crime as one of the most important civil rights and a key responsibility of government.” In short, as Kolb noted, "a populist civil rights agenda, emphasizing things like repeal of Davis-Bacon, and other structural impediments to good jobs, housing, safe streets, and equal opportunity."

Most of these suggestions found their way to the final version of the SOTU. Meditation on the values and principles allowed Bush Senior to transfer the responsibility of solving the nation's problem from the government to the people,

Tonight I come before this House and the American people with an appeal for renewal. This is not merely a call for new government initiatives; it is a call for new initiatives in government, in our communities, and from every American to prepare for the next American century. [...] The strength of a democracy is not in bureaucracy. It is in the people and their communities. In everything we do, let us unleash the potential of our most precious resource -- our citizens, our citizens themselves. We must return to families, communities, counties, cities, states, and institutions of every kind the power to chart their own destiny and the freedom and opportunity provided by strong economic growth. And that's what America is all about.

The appeal for active citizenship and culture of conscience which culminated in the final version of the SOTU had evolved in earlier drafts (e.g. Draft\#11, dated January 14). Over a dozen drafts of the SOTU were produced (Draft B-3, Jan. 29, 1991; Draft B-5, Lange/Grossman, Jan. 29, 1991; Draft ACE, Lange/Grossman, Jan. 29, 1991). As Draft \#8 and Draft\#11, both dated January 14, 1991, illustrate, the drafts crafted by Grossman and Lange were quite short, 12-14 pages.

In terms of their content, the drafts were statements of American values and goals rather than outlines of legislative proposals. For instance, Grossman suggested to "sell empowerment" - the new independence, "by appealing to the most basic of American values." Empowerment as Freedom and Independence, she argued, was consistent with the conservative agenda, which "often was couched in negative terms: anti-communism, anti-big government, anti-egalitarianism.” Yet, Grossman noted, "the common thread running through these anti's was pro-freedom, pro-individual freedom.” Grossman attempted to explain the idea of empowerment in many ways: as a concept that stresses the link between effort and reward ("Americans deeply believe in hard work"), and the work ethic versus the entitlement ethic, "Hand in hand with the work ethic is the belief in The American Dream, and faith that the ordinary American can achieve that dream." Grossman went on to argue that, "[t]he choice between the republican program and the bureaucratic welfare state was the choice between hope and despair; the American Dream versus "the deep and dreamless sleep [...]. The idea was to transform "the passive recipients of bureaucracies, to active self-confident members of 
their economy $[\ldots]$ and communities. Turning victims of poverty into creators of their own destiny."

Meditation on values was an important aspect of Bush Senior's SOTUs in general, including the 1991 SOTU. As two copies of excerpts of scholarly articles attached to the memo from Jennifer Grossman to Mark Lange (January 3, 1991) illustrate, Grossman consulted the Presidential Studies Quarterly (PSQ), and Western Journal of Speech Communication (WJSC) on values in presidential speeches. The PSQ study found that "Presidents sell and defend their programs and behavior through their conceptions of the American public and its values.” It concluded that "the relationships between presidential values and public priorities is highly interdependent, and that a change in individual presidents or parties, or eras, will not noticeably change the criteria by which national policies are advocated.” The copy from the WJSC listed over a dozen values to which the American public responds, including responsibility and cooperation, the value of the individual, equality of opportunity, hard work, efficiency, rejection of authority, generosity and considerateness, all of which resonate in Bush Senior's SOTUs.

By meditating on American values, as Grossman's (Grossman to Lange, Jan. 3, 1991) material for President Bush's 1991 SOTU indicates, Republicans wanted to recapture the "compassion market," where the Democrats still won out on the question who cared more about the ordinary American citizen. As the following post-SOTU note sent to the White House illustrates, some viewers liked the president's speech, "[o]ne more speech like the state of the union 1991 and your head will be the fifth one chiseled into the side of Mount Rushmore," (Thomas W. Moseley to President).

Debating and celebrating American values would not, however, help Bush Senior set a domestic agenda. Alan Brinkley's (The New York Times, January 29, 1991) critical review of the President's address suggests that the agenda shaped by crises may be revealing the lack of an agenda,

If anyone has a reason to be grateful for the war in the Persian Gulf, it is the unfortunate White House speechwriter responsible for President Bush's State of the Union Address this evening. Without an international crisis what would the President have to talk about? Perhaps no Administration in this century has completed two years in office so devoid of domestic accomplishments and uninterested in setting the domestic agenda. And there is no suggestion that anything will change soon. John Sununu captured the essence of the Administration's emptiness recently when he answered a question about what remained on the President's domestic agenda with a curt, 'Not that much.' Were it not for Saddam Hussein, the Bush Presidency would be nearly invisible.

As David Halberstam (2002, 57) notes, "Foreign policy, rather than domestic affairs, was the administration's area of expertise, interest, and passion.” Bush saw himself as a foreign policy president, and he lived up to this categorization. 


\section{Tony Snow and Robert H. Simon}

The head of media affairs Tony Snow and Robert H. Simon, a young speechwriter with a gift for writing, drafted President Bush Senior's 1992 SOTU. There was no essential difference in the organization of the work of each speechwriting team. Speechwriters did not write directly to President George H. W. Bush, nor did they receive any written instructions from him. Deputy Chief of Staff, James Cicconi, and not the speechwriters, requested the president's comments on drafts. Either the Chief of Staff, Sam Skinner, or Roger B. Porter, solicited and coordinated the material for the SOTU.

Although typically ideas were sought from the Administration officials in developing the overall themes and specific initiatives, ${ }^{3}$ under president Bush Senior, as also the preparation schedule illustrates, the locus of decision in policy development was, as David Q. Bates Jr. pointed out in an oral history interview, moved out of the hands of the departments toward "close to presidential or presidential staff control.” The SOTU core group usually included the White House staff. Bates' role would involve "significant liaison between the Cabinet members involved and Roger Porter."

As the SOTU drafts developed, they were circulated between the president and the core SOTU group. Comments on the drafts were sought from Vice President Quayle, Skinner, Scowcroft, Darman, Fitzwater, Gray, McClure, Porter, Boskin, and they were submitted to David Demarest (White House Briefing Memorandum).

A memo from Demarest to Skinner on the State of the Union (SOTU) Preparation Schedule, suggests that President Bush Senior's 1992 SOTU developed between January 20 and January 28. Tony Snow's Memorandum to Speechwriters and Researchers illustrates that in the second week of January 1992, it was safe to say that the State of the Union was "taking shape in a way that we will like.” The President's understanding of his 1992 SOTU (Cabinet meeting on January 28) was that, again, his address was

\footnotetext{
not a programmatic speech. We are not going to reference all the programs of government. We have to hit the issues which are on the minds of the American people: jobs and the economy. Tonight the American people are going to learn about our specific proposals for jobs and economic growth. [...] After tonight, it will then be up to Congress to pass our plan. But we are going to have to help them. We have got to get out there and resonate the message that it is important for Congress to pass our plan.
}

3. See for instance: Memo, Roger B. Porter to James B. Busey, January 17, 1992, WHORM: Subject File-Gen. Scanned Records, Office of Speechwriting, Bush Presidential Records, folder: SP 230-92, State of the Union 1992. Case No. 301022 to Case No. 301802, box 36. GBPL.

Memo, Porter to Edward R. Madigan, January 17, 1992, WHORM: Subject File-Gen. Scanned Records, Bush Presidential Records, folder: SP 230-92, State of the Union 1992. Case No. 301960 to Case No. 302829, box 39. GBPL. Memo, Nicholas Rostow to Brent Scowcroft, "State of the Union Speech,” January 9, 1992, WHORM: Subject FileGen. Scanned Records, Bush Presidential Records, folder: SP230-92, State of the Union 1992. Case No. 301892SS, box 36. GBPL. 
The series of dramatic events in Central and Eastern Europe, Latin America, and the Persian Gulf dominated the attention of the administration in 1990 and 1991, and as Shirley Anne Warshaw $(1996,192)$ points out, "eclipsed any domestic programs.” If George H. W. Bush, Warshaw $(1996,192)$ writes, “were going to be reelected in 1992, a clear domestic agenda had to be framed and at least partly implemented."

Even though the 1992 SOTU $^{4}$ was the highest-rated of the Bush Senior Administration, watched in 43 million households by 95 million viewers and the "Republican were uniformly positive, excited and gratified by the speech," most Democrats called it "warmed-over policies of the past or too little too late," (Dorrance Smith to the President). Moreover, Bush Senior challenged the Congress to pass his program by the March 20 deadline.

The deadline was an instrument of pressure, selected to transfer the responsibility for dealing with the recession from George H. W. Bush to Congress. Importantly, the deadline fell amid essential primaries in the Democratic presidential race (Doug Chia to Speechwriters and Researchers). Members of Congress were determined to win elections rather than fight for the common good, which is traditionally the president's responsibility (Review \& Outlook, Jan. 30, 1992).

\section{President George H. W. Bush's involvement in the SOTU process}

In the opinion of Chief of Staff, John Sununu (Interview with John H. Sununu), President Bush Senior did not use speeches as "substantive occasions to communicate a world view or policy priorities." The preferred structure of the president's SOTUs was a thematic, value-oriented, address rather than a programmatic address. Additional pages of the Draft \#3 indicate that George H. W. Bush believed that the departure was "warranted by the extraordinary times we live in." His intention was "to speak to you about the State of the Union-about the larger forces at work in the world and here at home.” Bush Senior's philosophy of government was that of stewardship and empowerment. His vision of America was that of active citizenship and culture of conscience.

The 1990 SOTU differed slightly from the established tradition in that the Budget Message was presented before the SOTU. That allowed the president to do

\footnotetext{
4. Bush's "detailed series of proposals" included "a budget that promotes investment in America's future-in children, education, infrastructure, space, and high technology; legislation to achieve excellence in education, building on the partnership forged with the 50 Governors at the education summit, enabling parents to choose their children's schools and helping to make America number one in math and science; a blueprint for a new national highway system, a critical investment in our transportation infrastructure; a research and development agenda that includes record levels of federal investment, and a permanent tax credit to strengthen private R\&D and to create jobs; a comprehensive national energy strategy that calls for energy conservation and efficiency, increased development, and greater use of alternative fuels; a banking reform plan to bring America's financial system into the 21st century so that our banks remain safe and secure and can continue to make job-creating loans for our factories, our businesses, and home buyers.”
} 
an address that discussed the assumptions and premises that went into the development of the budgets rather than reciting the budget details or a traditional "shopping list” of the Administration's programs, (Briefing by Senior Administration Offcials, Jan. 31, 1990). It was an opportunity for George H. W. Bush to give the American public "some background on the kinds of thinking that he has given to the issues that are important in America." Bush Senior wanted to present some specific pieces of legislation in the SOTU "more as examples of what flows from the process of development rather than saying and I am going to do this," and "here are the 17 points associated with that program."

As an undated State of the Union Draft Schedule indicates, the president would be familiar with the first draft. The White House staff updated the president on the writing progress, and drafts were sent to him, (State of the Union-1/29/90 Draft). The president's comments in his handwriting, though rare, could be identified on the drafts, (Handwritten notes by POTUS). Bush Senior's involvement in shaping the content of his SOTUs was somewhat limited and his relations with speechwriters rather distant.

\section{Conclusions}

One of the adverse developments associated with the rise of the Rhetorical Presidency is the appearance of specialized writers or wordsmiths in the White House. The speechwriting operations in the George H. W. Bush White House illustrate that the drafting process began quite late, only a couple of weeks before the SOTU. Federal departments submitted ideas for Bush Senior's SOTUs, but the core policy group would consist of the White House staff, the OMB and the Council of Economic Advisers.

Although the accounts of the White House staffers quoted in this study suggest that speechwriters participated in meetings with the president, speechwriters did not generate policy input; they were not top presidential advisors who also crafted speeches, but rather wordsmiths specializing in ceremonial rhetoric. Presidential coordinators served as intermediaries between the president and his speechwriters, which diminished their importance. Also, the reliance on writers who changed annually suggests a decreased interest of the Bush Senior Administration in producing policy-oriented SOTUs.

Bush Senior's thematic SOTUs were short on policy initiatives and legislative proposals needed to assert the president's legislative leadership. Bush failed as a legislative leader because he failed as a rhetorical leader to seize opportunities to bring about transformative change through deliberative rhetoric. Inspirational speeches can be effective acts of national unification. Generically, however, the 
SOTU is an intermixture of ceremonial and deliberative rhetoric. A thematic and ceremonial SOTU is not an indicator of a president's capacity to govern. Congress needs more than an annual review of American values and principles. By the power of the "recommending measures" clause that mandates the SOTU, the president is expected to assert himself at the beginning of the legislative process and make the best of the unique opportunity to persuade Congress to act on his domestic agenda.

It may seem paradoxical that the president who ignored a rhetorical dimension of the office and understood his role in negative terms as "the head of government," used a unique constitutional tool suited to the execution of his role as chief legislator to act as the leader of the people. One must note, however, that George H. W. Bush found himself when the United States played an important role in establishing a new world order. Americans could take pride in their values and spreading these values abroad. Historical circumstances called for Bush Senior's international leadership and provided him with an agenda in foreign policy in which he had previous experience as the U.S. Ambassador to the UN, U.S. envoy to China, CIA director, and Vice President.

President George H. W. Bush's thematic and largely ceremonial SOTUs reflect his attitude to rhetoric and communication. For George H. W. Bush, the presidency was not a bully pulpit, and he did not use the opportunity offered by the SOTU to assert his legislative leadership. Instead George H. W. Bush's preference for value-oriented SOTUs suggests that he understood his role as the guardian of American values, and his presidency as the place of moral leadership.

\section{References}

\section{Archival Sources}

Additional pages of the Draft \#3, WHORM: Subject File-Gen, Bush Presidential Records. Folder: SP 230-90 State of the Union-1990 [6] Case No. 128526SS, box 33. GBPL.

Briefing by Senior Administration Officials, January 31, 1990. WHORM: Subject File Gen., Bush Presidential Records, folder: SP 230-90 State of the Union-1990 [8] Case No. 128526SS, box 89. The George Bush Presidential Library (GBPL).

Cabinet Meeting, January 28, 1992, folder: 1/28/92, Presidential Daily Backup, Bush Presidential Records, box 91. GBPL.

Draft, February 5, 1989 Draft. "Message of President George Bush to a Joint Session of Congress, February 9, 1989. "Bush Presidential Records Office of Speechwriting, Speech File-Backup. Folder: Address to Joint Session of Congress 2/9/89(OA6353)[2], box 2. GBPL.

Draft, McGroarty/Dooley Draft, January 11, 1990. WHORM: Subject File-Gen. Bush Presidential Records, folder: SP230-90 State of the Union-1990[6] Case No. 128526SS, box 33. GBPL

Draft, Draft \#2 (5:45 p.m.) State of the Union, January 18, 1990. WHORM: Subject File-Gen. Bush Presidential Records, folder: SP 230-90 State of the Union-1990[6] Case No. 128526SS, box 33. GBPL.

Draft, January 29, 1990, folder: State of the Union, 1/31/90[4],(OA9316), Office of Speechwriting, Bush Presidential Records, box 49. GBPL. 
Draft, McGroarty/Dooley draft, January 29, 1990, folder: State of the Union Address, 1/31/90(OA4391) (2), Office of Speechwriting, Bush Presidential Records, box 45. GBPL.

Draft, 10:30 Draft of the President's State of the Union Message, January 31, 1990, folder: State of the Union 1/31/90 [OA9310][1], Office of Speechwriting, Bush Presidential Records, box 49. GBPL.

Draft, "Latest"-2:25 p.m. Draft of the President's State of the Union Message, January 31, 1990, folder: State of the Union 1/31/90 [OA9310][1], Office of Speechwriting, Bush Presidential Records, box 49. GBPL.

Draft \#8, Jennifer Grossman \& Mark Lange, January 14, 1991, "State of the Union Material,” Bush Presidential Records, Office of Speechwriting, folder: State of the Union Address, 1/29/91, box 81. GBPL.

Draft \#11, Jennifer Grossman \& Mark Lange, January 14, 1991, “State of the Union Material,” Bush Presidential Records, Office of Speechwriting, folder: State of the Union Address, 1/29/91, Box 81.

Draft, Lange/Grossman State of the Union Address Draft B-1, January 28, 1991, WHORM: Subject File-Gen., Scanned Records, Bush Presidential Records, folder: State of the Union 1991, case number 214783SS[3], box 35. GBPL.

Draft, Lange/Grossman State of the Union Address Draft B-3. January 29, 1991. Subject File-Gen. Scanned Records, Bush Presidential Records, folder: State of the Union 1991, case number 214783SS[3], box 35. GBPL.

Draft, Draft B-5, Lange/Grossman, January 29, 1991, folder: State of the Union 1/31/90 [OA8210] [1], Office of Speechwriting, Bush Presidential Records, box 49. GBPL.

Draft, Draft ACE, Lange/Grossman, January 29, 1991, folder: State of the Union 1/31/90 [OA8210] [1], Office of Speechwriting, Bush Presidential Records, box 49. GBPL.

Draft, January 26, 1992, folder: State of the Union Address, 1/28/92 (OA7567), Office of Speechwriting, Bush Presidential Records, box 142 [1]. GBPL.

Draft, McGroarty/Dooley Draft \#2, January 18, 1990, 5:45 p.m., folder: State of the Union Address, 1/31/90 (OA4391) (2), Office of Speechwriting, Bush Presidential Records, box 45. GBPL.

Draft with Bob Grady's and OMB's comments, 7:30 a.m. draft, January 28, 1992, WHORM: Subject File-Gen. Scanned Records, Bush Presidential Records, folder: SP230-92, State of the Union 1992, Case Number 301892 + case number 301892SS[3], box 36. GBPL.

Draft, January 28, 8:00 a.m. draft 1992, WHORM: Subject File-Gen. Scanned Records, Bush Presidential Records, folder: SP 230-92, State of the Union 1992. Case Number 301892SS[6], box 37. GBPL.

Fact Sheet, The President's State of the Union Message Fact Sheet, WHORM: Subject File-Gen., Bush Presidential Records, folder: SP 230-90 State of the Union-1990 Case No. 128526SS. Box 32. GBPL.

Final Changes, "Message of President George Bush to a Joint Session of Congress, February 9, 1989.” Draft February 9, 1989, 6 AM. Bush Presidential Records Office of Speechwriting, Speech File-Drafts. Folder: Joint Session of Congress 2/9/89 [OA2771] [3], box 2. GBPL.

Handwritten notes by POTUS, RE: State of the Union Address draft, WHORM: Subject File-Gen., Bush Presidential Records, Open P2/P5 Documents, Case Number 128526SS[3]. GBPL.

Letter, Roger B. Porter to Richard H. Truly, December 14, 1989, WHORM: Subject File-Gen., Bush Presidential Records, folder: SP 230-90 State of the Union-1990[6] Case No. 129361 to Case No. 308099. GBPL.

Letter John Akers, Jim Burke, Ray Chambers, Tom Kean, David Kearns to President Bush, January 15, 1991. Bush Presidential Records, WHORM-Subject File-Gen., Scanned Records, folder: SP 230-71, State of the Union 1991, box 35. GBPL. 
Meeting Minutes, Meeting with Speechwriters, January 16, 1990, WHORM: Subject File-Gen., Bush Presidential Records, folder: SP 230-90 State of the Union-1990, Case No. 115224 to Case No. 197301, box 34. GBPL.

Memo, Roger Porter to Samuel K. Skinner, December 11, 1989, WHORM: Subject File-Gen., Bush Presidential Records, folder: SP 230-90 State of the Union-1990, Case No. 115224 to Case No. 197301, box 34. GBPL.

Memo, Roger B. Porter to Lauro F. Cavazos, December 20, 1989, WHORM: Subject File-Gen., Bush Presidential Records, folder: SP 230-90 State of the Union-1990[6], Case 110 No. 129361 to Case No. 308099. GBPL.

Memo, David Demarest to the President, "State of the Union Address," December 11, 1989. Bush Pres. Records WHORM-Subject File-Gen. Folder: SP 230-90 State of the Union-1990 [6] Case No. 129361 to case no 308019. GBPL.

Memo, President to David Demarest, "State of Union," December 15, 1989, WHORM: Subject FileGen., Bush Presidential Records, folder: SP 230-90 State of the Union-1990[6] Case No. 129361 to Case No. 308099. GBPL.

Memo, James Cicconi to the President, January 12, 1990, WHORM: Subject File-Gen. Bush Presidential Records, folder: SP230-90 State of the Union-1990[6] Case No. 128526SS. Box 33. GBPL.

Memo, Hanns Kuttner to Roger B. Porter, „Ideas/Themes for Budget/ State of the Union Cycle,” November 4, 1990, folder: Open P2/P5 Documents, Documents 15,301-15,550, box 55. GBPL.

Memo, Michael L. Williams to Chino Chapa, "State of the Union Briefing Part II," November 29, 1990, folder: Open P2/P5 Documents, Documents 10,101-10,450, box 36. GBPL.

Memo, Charles E. M. Kolb to Roger B. Porter, "State of the Union Themes," December 4, 1990, Open P2/P5 Documents, Documents 2201-2250, Case Number 198181, WHORM: Subject FileGeneral, Bush Presidential Records. GBPL.

Memo, Roger B. Porter to Governor Sununu, "State of the Union Address: Themes," for drafting the outline of the SOTU on December 31, 1990. GBPL.

Memo, Jennifer Grossman to Mark Lange, January 3, 1991, "State of the Union Material," Bush Presidential Records, Office of Speechwriting, folder: State of the Union Address, 1/29/91, box 81. GBPL.

Memo, Roger Porter to Bill Kristol, January 16, 1991, WHORM: Subject File-Gen. Scanned Records, Bush Presidential Records, folder: SP 230-91, State of the Union 1991, Case No. 218133 to Case No. 222943, box 36. GBPL.

Memo, Mark Albrecht to Roger Porter, January 15, 1991. Bush Presidential Records, WHORM: Subject File-Gen. Scanned Records, folder: SP 230-91, State of the Union 1991, Case No. 218133 to Case No. 222943, box 36. GBPL.

Memo, Tony Snow to Speechwriters and Researchers, "State of the Union and other Stuff," January 8, 1992, Open P2/P5 Documents, Documents 6451-6750, box 22. GBPL.

Memo, David Demarest to Sam Skinner, "State of the Union (SOTU) Preparation Schedule, January 18, 1992, WHORM: Subject File-Gen. Scanned Records, Bush Presidential Records, folder: SP 230-92, State of the Union 1992. Case Number 312306 to case no 315632, box 38. GBPL.

Memo, Dorrance Smith to the President, "Television Rating Comparisons for your State of the Union Addresses,” January 31, 1992. Bush Presidential Records, WHORM-Subject File-Gen.. Scanned Records. Folder: SP 230-92, State of the Union 1992. Case Number 30270404 to case number [illegible], box 37. GBPL.

Memo, Doug Chia to Speechwriters and Researchers, "Complaints about March 20 Deadline," January 30, 1992. Bush Presidential Records, Office of Speechwriting. Folder: State of the Union Address, 1/28/92, box 142. GBPL. 
Miller Center. Interview with David Q. Bates Jr., University of Virginia, September 21-22, 2000. http://millercenter.org/president/bush/oralhistory/david-bates

Miller Center. Interview with John H. Sununu (06/2000). Recorded interview by Sid Milkis. University of Virginia, June 8-9, 2000, http: //millercenter.org/president/bush/oralhistory/john-sununu-1

Note, James Cicconi to Chriss Winston, January 30, 1990, folder: State of the Union Address, 1/31/90(OA4391)(2), Office of Speechwriting, Bush Presidential Records, box 45. GBPL.

Note, James W. Cicconi to Director Darman, January 30, 1990, folder: State of the Union Address, 1/31/90 (OA4391)(2), Office of Speechwriting, Bush Presidential Records, box 45. GBPL.

Note, C. Boyden Grey to David Demarest, January 28, 1992, WHORM: Subject File-Gen. Scanned Records, Bush Presidential Records, folder: SP 230-92, State of the Union 1992. Case Number 301892SS[4], box 31. GBPL.

Note, G. Philip Hughes to J. Stapleton Roy, State of the Union Address, January 26, 1990, WHORM: Subject File-Gen., Bush Presidential Records, folder: SP230-90 State of the Union-1990[6] Case No. 128526SS, box 33. GBPL.

Note, undated, Charles Kolb to Tony Snow, Open P2/P5 Documents. Documents 2001—2400, BOX 8. GBPL.

Outline, State of the Union, January 29, 1990. Bush Presidential Records, Office of Speechwriting. Folder: State of the Union Address, 1/31/90(OA4391)(2), box 45. GBPL.

President's Talking Points, undated, folder: State of the Union Address, 1/31/90 (OA 4391)(2), Office of Speechwriting, Bush Presidential Records, box 45. GBPL.

Peri, Sarada. "Translating presidential ideas into words: Speechwriters in the White House.” May 21-23, 2019, University of Virginia, Miller Center, 1:24, https://millercenter.org/prezfest2019/ prezfest-videos/whitehouse-speechwriters

Post state of the union note, Thomas W. Moseley to President Bush, January 30, 1991. Bush Presidential Records, Subject File-Gen.. Scanned Records, folder: State of the Union 1991, box 35. GBPL.

Post-state of the union note, Al Flora to President Bush, February 6, 1991. Bush Presidential Records, Subject File-Gen.. Scanned Records, folder: State of the Union 1991, box 35. GBPL

State Department Suggested Changes to State of the Union Address, January 26, 1990. WHORM: Subject File-Gen., Bush Presidential Records, folder: SP230-90 State of theUnion-1990[6] Case No. 128526SS, box 33. GBPL.

State of the Union Draft Schedule, undated, folder: SP 230-90 State of the Union-1990 [6] Case No. 128526SS. WHORM: Subject File-Gen, Bush Presidential Records, box 33. GBPL.

The Advanced Text of Remarks by the President on the State of the Union, January 31, 1990, WHORM: Subject File-Gen. Bush Presidential Records, folder: SP 230-90 State of the Union-1990 Case No. 128526SS, box 32. GBPL.

The American Presidency Project, George Bush, Address Before a Joint Session of the Congress on the State of the Union Online by Gerhard Peters and John T. Woolley, https://www.presidency. ucsb.edu/node/265956

The Annual Report To Congress On White House Office Personnel, June 28, 2019, White House Office, https://www.whitehouse.gov/wp-content/uploads/2019/06/July-1-2019-Report-FINAL.pdf

The White House Staffing Memorandum, James Cicconi to Scowcroft, Darman, Grey, Porter, Boskin, "State of the Union-1/29/90 draft, January 29, 1990, folder: State of the Union Address, 1/31/90 (OA4391) (2), Office of Speechwriting, Bush Presidential Records, box 45. GBPL.

Undated possible inserts for State of the Union '90, folder: Open P2/P5 Documents. Documents 15,851-16,280, box 58. GBPL. 
The White House Staffing Memorandum, Presidential Address: State of the Union (Revised Version) U.S. Capitol, House Chamber, January 28, 1992, WHORM: Subject File-Gen. Scanned Records, Bush Presidential Records, folder: SP230-92, State of the Union 1992, Case Number 301892+case number 301892SS[3], box 36. GBPL.

White House News Summary, Network Television Coverage following the President's State of the Union Address, Wednesday 31, 1990. Bush Presidential Records, Office of Speechwriting, folder: State of the Union 1/31/90 [OA 9310] [1], box 49. GBPL.

“Will George do It?” Review \& Outlook, January 30, 1992. Bush Presidential Records, Office of Speechwriting, folder: State of the Union Address, 1/28/92, box 142. GBPL.

\section{Secondary Sources}

Campbell, Karlyn K., and Kathleen Hall Jamieson. 1990. Deeds Done in Words: Presidential Rhetoric and the Genres of Governance. Chicago: University of Chicago Press.

Ceaser, James W., Glen E. Thurow, Jeffrey Tulis and Joseph M. Bessette. 1981. "The Rise of the Rhetorical Presidency.” Presidential Studies Quarterly 11 (2): 158-171.

Cohen, Jeffrey E. 2009. "Alternative Features: Comment on Terry Moe's 'The Revolution in Presidential Studies.’” Presidential Studies Quarterly 39 (4): 725-35.

Collier, Kenneth. 2018. Speechwriting in the Institutionalized Presidency: Whose Line Is It? Lanham: Lexington Books.

Denton, Robert E. Jr., and Gary C. Woodward. 1998. Political Communication in America. Westport: Praeger.

Dorsey, Leroy. 2002. “Introduction: The President as a Rhetorical Leader.” In The Presidency and Rhetorical Leadership, ed. Leroy Dorsey. College Station: Texas A\&M University Press.

Griffin, Charles J. G. 2003. "Dwight D. Eisenhower. The 1954 State of the Union Address as a Case Study in Presidential Speechwriting." In Presidential Speechwriting: from the New Deal to the Reagan revolution and beyond, ed. Kurt Ritter and Martin J. Medhurst, 68-91. College Station: Texas A\&M University Press.

Halberstam, David. 2002. War in a Time of Peace: Bush, Clinton and the Generals. London: Bloomsbury Publishing.

Heidt, Stephen J. 2018. "Introduction: The Study of Presidential Rhetoric in Uncertain Times: Thoughts on Theory and Praxis." In Reading the Presidency. Advances in Presidential Rhetoric. Series: Frontiers in Political Communication, ed. Stephen J. Heidt and Mary E. Stuckey.

Hill, D. M., and P. Williams, ed. 1994. The Bush Presidency. Triumphs and Adversities. New York: St. Martin's Press.

Hoffman, Donna R., and Alison D. Howard. 2006. Addressing the State of the Union: The Evolution And Impact of the Presidents' Big Speech. Boulder: Lynne Rienner Publishers.

Hult, Karen M., and Charles E. Walcott. 1998. "Policymakers and Wordsmiths: Writing for the President under Johnson and Nixon.” Polity 30 (3): 467.

Kalb, Deborah, Gerhart Peters, and John T. Wooley, ed. 2007. State of the Union: Presidential Rhetoric from Woodrow Wilson to George W. Bush. Washington, DC: CQ Press.

Medhurst, Martin J. 1996. "A Tale of Two Constructs: The Rhetorical Presidency Versus Presidential Rhetoric.” In Beyond the Rhetorical Presidency, ed. Martin J. Medhurst, xi-xii. College Station: Texas A\&M University Press.

Langford, Catherine L. 2006. "Bush's Struggle with the 'Vision Thing'." In The Rhetorical Presidency of George H. W. Bush, ed. Martin J. Medhurst, 19-36. College Station: Texas A\&M University Press. 
Rose, Richard. 1991. "George Bush as a Postmodern President.” Studies in Public Policy number 191. Glasgow: Center for the Study of Public Policy.

Rozell, M. 1989. “In Reagan's Shadow: Bush's Antirhetorical Presidency.” Presidential Studies Quarterly 28 (1): 127-139.

Schlesinger, Robert. 2008. White House Ghosts. Presidents and their Speechwriters from FDR to George W. Bush. New York: Simon \& Schuster.

Świątczak-Wasilewska, Iwona. 2014. "The Toughest Season in the White House:” The Rhetorical Presidency and the State of the Union Address, 1953-1992. Doctoral Dissertation, University of Helsinki.

Tulis, Jeffrey K. 1987 (2017). The Rhetorical Presidency. Princeton: Princeton University Press.

Warshaw, Shirley Anne. 1996. Powersharing: White House-Cabinet Relations in the Modern Presidency. Albany: SUNY Press.

Windt Jr. Theodore Otto. 1986. "Presidential Rhetoric: Definition of a Field of Study.” Presidential Studies Quarterly 16 (1): 102-116. 